\title{
May He Speedily Come \\ The role of the Messiah in Haredi and Hardal Judaism
}

\author{
MIA ANDERSSÉN-LÖF
}

\begin{abstract}
This his article studies the understanding of redemption in general, and in particular the role of the Messiah in redemption as it is expressed by representatives of two Jewish perspectives: the Haredi (ultra-Orthodox) and the Hardal (nationalist ultra-Orthodox). Although both perspectives see the shift from exile to redemption as an event which is brought about by God, both also see ways to accelerate or decelerate that event. Both have developed a strategy according to their respective interpretations of how the shift from exile to redemption will appear. To the Haredim, the solution calls for the Jewish people to repent, live piously and wait for the Messiah to emerge; to the Hardalim, the solution calls for the Jewish people to abandon the passive approach and engage in the process of redemption, which has already begun even though the Messiah delays. Hence, both present a strategy for expediting the End, and can thus be considered messianic.
\end{abstract}

This article compares the understanding of the role of the Messiah in redemption in two contemporary perspectives of Judaism; Haredi and Hardal, in this article represented by the True Torah Jews Against Zionism and Neturei Karta on one hand, and by R. Tzvi Yehuda Kook and the Temple Institute on the other. Briefly put, for the Haredim, redemption will begin with an impetus from the Messiah; for the Hardalim, advances in the process of redemption are the spark that will bring about the Messiah. Although both perspectives see the shift from exile to redemption as an event brought about by God, both perspectives also see ways to accelerate or decelerate that event.

One may, perhaps, formulate the question which produced this division of minds more pointedly. It would then be: Can man master his own future? ${ }^{1}$ (Scholem I 97 I: I4-I 5)

1 Gershom Scholem ( 197 I: I 4-I 5) views the development of two kinds of messianisms; one which 'corresponds to and originates from the ... conception of the essential lack of relation between human history and the redemption', and another in which 'utopianism becomes the lever by which to establish the Messianic kingdom'. 
The discrepancy between the two perspectives is visible in their conceptions of how to influence the shift from exile to redemption. The form of Haredi Judaism represented in this article sees the Messiah as a sine qua non of redemption, and furthermore perceives redemption and exile as two conditions exclusive of each other. Consequently, since the Messiah has not emerged (candidates can be tested against unambiguous criteria), the time of redemption has not yet come, and, it follows, the Jewish people are still in exile. During exile, a spirit of repentance is held to be an ideal, which is why an attitude of passivity has come to dominate many aspects of life (Ravitzky I 993: I 3-22).

But it is impossible, for most of them, to pass through apocalyptic events such as the Holocaust, or to experience the end of exile and the reestablishment of Israel as a sovereign commonwealth, without the stirring of messianic chords in their souls (Werblowsky 2005:5978).

The Hardal (an acronym for Haredi dati leumi, or nationalist ultra-Orthodox), is a subcategory of religious Zionism. To the Hardalim represented in this article, the unfolding of history, particularly the dramatic events of the twentieth century - with the highest points being the establishment of the State of Israel and the military triumphs of the Six Day War - reveals that God is now restoring his people. Exile has ended and redemption has begun. The regulations of life in exile no longer apply. Instead, this perspective sees it as a religious obligation to engage in the process of redemption. There is, however, no consensus as to the concrete expression of this engagement: some enhance the necessity of expanding the State of Israel to correspond to the idea of the Promised Land, some rank more highly the process of gathering the exiles first, and some concentrate on rebuilding the Temple of Jerusalem. The underlying ideo-theology has its tenets far back in the Jewish tradition, but was brought to the fore by the R. Abraham Yitzhak ha-Cohen Kook (I865-I935), and his son, R. Tzvi Yehuda Kook ( 1891-1982), whose yeshiva, Merkaz Harav, became a greenhouse for Hardal Judaism (Sacks I 992: 69; Sharot I 982: 226-7).

\section{Definitions and demarcations}

The two overlapping organizations, True Torah Jews Against Zionism (JAZ) and Neturei Karta (NK), both define themselves as Orthodox Jews, although they are generally referred to as ultra-Orthodox or Haredim (Friedman 2007: I I 4; Friedman and Derovan 2007: 742; Rubinstein 2007: 582 ). Haredi Judaism designates 
the most extreme of Orthodox Jews who, although they have changed over time, claim to have made no compromises with contemporary secular culture or essential changes in the way they practice their Judaism from what the tradition and halakbah have sanctified throughout the ages (Heilman and Skolnik 2007: 349).

I will be referring to primary material published by JAZ and NK: firstly, website material from the respective official websites, secondly the book by Yakov M. Rabkin, A Threat From Within: A Century of Jewish Opposition to Zionism (2006), to which JAZ has referred me for their views on exile and redemption. Also NK recommends Rabkin's book on their website (NK 20 5 a). Thirdly, I will be referring to Yirmiyahu Cohen's book In the Footsteps of the Flock: The Views of the Gedolei Hatorah on Exile, Redemption and Eretz Yisroel Arranged According to the Weekly Torah Readings (2007), published by JAZ.

For the other perspective represented in this article, that of the Hardal is characterized by Nadav Shelef (2010: 183; cf. Cohen and Kampinsky 2006: I20) as 'religious observance in the Haredi style combined with an uncompromising nationalist position as developed by the leaders of Mercaz Harav Yeshiva,' distinguishing itself as a particular category after the Six Day War in I 967 (Arian 2009: 80).

The usage of the term 'Hardal' varies somewhat in the scholarly discourse. Yoel Cohen (2014: 62, 96, I00, I4I) depicts Hardal as a stricter form of mainstream modern orthodoxy, a combination of the 'Haredi separatist view of modern culture but a nationalist or leumi view of nationalism and the Zionist state'. On the other hand, Cohen distinguishes between hardal and dati leumi (nationalist religious), which he sees as a synonym for modern Orthodox (ibid. I 5 I). In this article I will go with the definition of Nadav Shelef, according to which the stringent religious observance and the ideo-theological influence of the Merkaz Harav Yeshiva are typical of the Hardalim. When describing the Hardal at an organizational level, Shelef mentions organizations stemming from Gush Emunim, such as the contemporary Manhigut Yehudit and $\mathrm{Zo}_{\mathrm{o}}$ Artzeneinu (Shelef 2010: I 8 I-2). However, as Richard T. Antoun remarks, one should bear in mind that this perspective is a loose structure, both socially and theologically:

It is likely that the followers and sympathizers of both Gush Emunim and other Jewish fundamentalist parties are connected (each within its own movement) in a social network that has particular nodes in religious schools, cooperative and collective settlements, parties and political lobbies. (Antoun 200I: 25-6) 
Another interesting aspect of the categorization is the relation between the Haredim and Hardalim. Shelef notes that religious Zionism has shifted from its proximity to secular Zionism - which turned out to be a misguided attempt at cooperation - to a 'growing social, cultural and theological proximity between this segment of Religious Zionism and the Haredi world':

The decreasing cultural gap between religious Zionism and the ultraOrthodox world symbolized by the Hardal is evident primarily, though not exclusively, in the growing religious radicalization of the Religious Zionist movement. This increased religious fanaticism was not limited to the margins of the movement but was spearheaded by the graduates of the Merkaz Harav Yeshiva. (Shelef 20 Iо: I 83)

Hardal Judaism is represented in this article by I) R. Tzvi Yehuda Kook, son of the founder of the Merkaz Harav Yeshiva and furthermore its rosh yeshiva, and 2) The Temple Institute (TI), founded and led by the Merkaz graduate R. Yisrael Ariel.

As primary material, I will refer to material on the official website of TI, as well its publication entitled Carta's Illustrated Encyclopedia of The Holy Temple in Jerusalem (2005) by R. Yisrael Ariel and R. Chaim Richman. I will also refer to R.T.Y. Kook's speech on Yom Ha'atzmaut of I 967, published by Merkaz Harav Yeshiva ( $\mathrm{MH}$ 2015a).

When referencing biblical passages, the translation by the International Bible Society, I979 (NIV) is used. The Sonico Edition of the Babylonian Talmud is also cited.

\section{The emergence of two perspectives}

Judaism has a wide spectrum of traditions regarding eschatology. Although the dominant tendency since the diaspora began has been to emphasise the virtue of enduring in exile - a form of passive messianism - an alternative, active messianism has flared up from time to time (Ravitzky i993: 19-32, Myers I991: 4). Robert Eisen (201 I: I47-54) defines passive messianism as a theology in which redemption 'comes primarily through divine initiative', and in which 'the influence of human beings on the messianic process is limited':

In this approach, views range from the belief that the events of the redemptive process proceed according to a strictly predetermined divine plan to the belief that repentance can bring the messiah; however, even according to the 
latter viewpoint, messianic redemption is seen as resulting primarily from God's wilful intervention in history. (Eisen 20 I I: I 47)

In active messianism it is also God who brings about redemption, but in contrast to passive messianism, human beings are crucial participants in the process. Whenever a man (especially, but not exclusively, if he is Jewish) perceives that the messianic process has begun, he must find a way to contribute to it, to bring it to completion. Active messianism is often associated with religious Zionism, although according to Joel Kraemer, Jewish theologians as early as Maimonides also accord with its definition:

Maimonides wrote the Mishneh Torah and the Guide of the Perplexed to reconstitute the Jewish people as strong, wise, and understanding, to prepare it for the anticipated messianic age. This was an active Messianism built on natural preparation, not a passive Messianism based on eschatological visions of divine interventions. ${ }^{2}$ (Kraemer 2006: 34 )

From the nineteenth century onwards, the interpretation of redemption as a process gained momentum. Arie Morgenstern (2006: 202) sees the Gaon of Vilna ( $1720-92)$ as a precursor to this thinking. His disciples were 'caught up in a messianic ideology' in which settling in Palestine and rebuilding Jerusalem would advance the process of redemption.

Many representatives of traditional Judaism, against which this was a radical break, held that an en masse emigration to Palestine would constitute a violation against the regulations of life in exile. ${ }^{3}$ The creative theology of R. Kalisher (I 795-I874) and R. Alkalai (I 798-I 878) provided a justification for deviation from the ways of the fathers, although it was widely banned as heresy (Fishman and Inbari 201 I: 620$).^{4}$

2 Yael Sagiv-Feldman (1 979: го7-го) sees a development in Maimonides' understanding of eschatology from the early compositions to the later; he 'moves from historical assurances of the coming redemption to a definite prohibition of any calculation of the End of Days'. Already in his Epistle to Yemen, he expresses his belief in the advent of the Messiah, but it is in the later Mishneh Torah that his 'unique conception' of the Messiah and redemption 'springs out in full bloom'.

3 Two of the most prominent representatives of the anti-Zionist position was the Rebbe of Munkács, R. Hayyim Eleazar Shapira and the Satmar Rebbe, R. Joel Moshe Teitelbaum (Ravitzky I 993: 40-5 I).

4 R. Kalisher and R. Alkalai are often portrayed as 'pioneers of religious Zionism'. The development of the perspective is described thoroughly by Dov Schwartz (2009) and Raymond Goldwater (2009). 
The weight of the theological argumentation was, however, not the only feature granting the success of religious Zionism. Robert Eisen (20 I I: 5) notes that 'religious Zionism would not have become such a potent source of violence nowadays, had it not been for the assistance it received from secular Zionists in its earlier decades'. Jacob Katz sees that

Jewish society achieved its nationalist transformation with the appearance of a modern idea, later called Zionism, which purged, so to speak, Jewish messianic belief of its miraculous eschatological elements and retained only its political, social, and some of its spiritual objectives. Even in this phase of development, however, Zionism leaned heavily on the old messianism and derived from it much of its ideological and even more of its emotional appeal. (Katz 2007: 540)

According to David Vital (1989: 348-9), the ideology of Zionism was developed in retrospect, which is why the dogma of Zionism presents 'a patchy and unsystematic appearance'. Its development can be systematized as threefold, with the Mizrahi distinguishing itself as a party in the World Zionist Organization in 1902 as a first step, the workers' party Ha-Po'el ha-Mizrahi forming in Palestine in 1922 under the slogan 'Torah ve-Avodah' as a second, and the emergence of Gush Emunim, for which the yeshiva Merkaz Harav was the ideological cradle, as a third (Fishman and Inbari 20 I I: 620; haCohen et al. 2007: 630; Feige 2009: 24; Lustick I988: 32).

R. Abraham Y. Kook (1865-r935) founded the Merkaz Harav in I924, in Jerusalem ( $\mathrm{MH}_{20 \mathrm{I}} \mathrm{b}$ ). Central to his thinking was a form of active messianism. He interpreted the national awakening of the Jewish people as the beginning of the End that would, in time, lead to the full redemption of Israel (Eisen 20I I: I47; Inbari 2009: I 8; Schwartz 2002: I23-4). R. A. Kook, like Kalisher, Alkalai and other harbingers of religious Zionism were 'driven by a kabbalistic-messianic outlook' (Schwartz 2002: I 24). In R. A. Kook's view, the State of Israel was 'the foundation upon which rests the Throne of God in this world' (MH 20 I 5c). His son, R. Tzvi Yehuda Kook, followed in his footsteps and became the mentor of religious Zionism from the establishment of the Israeli State until his death in I98 I (Ravitzky 1993: 79). Reuven Firestone (2OI2: 278) perceives him as a charismatic figure that 'succeeded in channelling the energy of a generation of enormously talented young people to engage in militant activism for the settlement-conquest of the Land of Israel'. Also Michael Feige highlights R. Tzvi Yehuda Kook's contribution: 
Kook the Son presented them [the young religious Zionists of the Merkaz haRav Yeshiva] with an ideology that placed the victorious project within a religious framework and assigned his followers a privileged position with respect to other groups. This encounter of an enthusiastic young group, the message of the yeshiva, and the historical opportunity provided by the SixDay and the Yom Kippur wars, helps explain why the movement emerged in the form that it did. Feige 2009: 27)

As R. J. Zwi Werblowsky (2005: 5977) points out, a tendency to 'messianize' politics has become notable, particularly within the religious Zionist perspective, since the war of I 973. A noteworthy development after the Oslo Accords, Shelef notes (2010: I82), is the growth of the Hardal, both numerically and theologically. There has been a tendency towards a 'Haredization' within the perspective; for example, the role of the rabbi is enhanced while the role of the political leadership is diminished; Haredi attributes, like fashion, are taken on by the Hardalim. Shelef interprets this development as a hint of the 'desired proximity to the Haredim'.

To conclude, the Haredi and the Hardal are two (ultra-)Orthodox perspectives, that in response to the existential challenges history has presented the Jewish people with, have developed contrasting interpretations of redemption, and subsequently, formed contrasting imperatives.

Cognitive dissonance ${ }^{5}$ occurs when reality, as it is perceived, does not meet with expectations. The response to cognitive dissonance is often radicalization (Inbari 2009: I2-I3). Ravitzky estimates (I993: 60) that the radical element of Haredi Judaism, although statistically marginal, have an indirect influence 'widely felt in the Haredi mainstream'. It has 'taken a consistent ideological line for nearly two generations' and is powerful in 'drawing the larger community into repeated confrontations with Israeli society and its institutions'. Regarding the Hardalim, Eisen (2013: I47-5 I) notes that a 'virulent strain of religious Zionism ... has come to the fore in recent decades', but in contrast with the Haredim, religious Zionism has gone from 'a relatively marginal phenomenon

5 Leo Festinger's theory of cognitive dissonance proposes that discrepancies between beliefs, ideas or values create mental stress; cognitive dissonance. In the pursuit of consistency there is a propensity to prefer solutions that maintain already accepted beliefs and ideas of value intact. Hence, the battle between the previously accepted information and the new, contradictory information is generally won by the former, even when achievement of consistency between the two requires a highly creative interpretation. Leo Festinger and his colleagues examined these dynamics in When Prophecy Fails (Festinger et al. I964; cf. O'Leary 2000: 34I-3). 
in Israeli society and politics to one that had a strong influence on the entire national agenda'.

In its declaration of its raison d'être, JAZ comes to the heart of the matter: it is a question of two irreconcilable ways of understanding redemption:

It is our hope that all of our fellow Jews will soon open their eyes, return to Torah and reject this ideology that replaces the Jew's age-old hope for $\mathrm{G}$-d's redemption with a false redemption and a human-initiated state. (JAZ 20 I $_{5}$ )

\section{The Haredi understanding of the Messiah}

Traditionally, Jewish existence is thought to be characterized by a pendulum motion between exile (Heb. galut) and redemption (Heb. geula). This motion is seen to be both divinely orchestrated and caused by the obedience or disobedience of the Jewish people. If the people strays from God, it brings an exile upon itself, but if it then repents and resorts to abiding in faith, God will have mercy upon it and redeem it.

The first biblical reference to this existential dynamic is found in Deut. 28-30 (Rabinowitz 2007: 789). The Jewish people is warned that if it doesn't carefully follow all the commands and decrees of the Lord, he will 'put an iron yoke on your neck until he has destroyed you' (28:48), and 'bring a nation against you from far away' (28:49), who will 'besiege all the cities throughout the land' $(28: 52)$ and hence, the people will be 'uprooted from the land' $(28: 63)$. Thus, the exile has begun $(28: 64-6)$. But there is also a promise that if the people returns to the Lord and obeys him with all its heart, wherever it is dispersed among the nations (30:I-2), he will have compassion and gather it to himself (30:4-5).

An integral element in the concept of exile is the Talmudic tradition of the threefold oath. BT Ketubbot I Iob-i I a holds a tradition that before going into exile, the Jewish people gave an oath that regulates life in the exile in three essential ways:

One, that Israel shall not go up [altogether as if surrounded] by a wall; the second, that whereby the Holy One, blessed be He, adjured Israel that they shall not rebel against the nations of the world; and the third is that whereby the Holy One, blessed be He, adjured the idolaters that they shall not oppress Israel too much'. And Rab Judah? - It is written in Scripture, That ye awaken not, nor stir up. (BT Ketubbot i rob-i I Ia) 
The fear of breaking out of the exile prematurely - of forcing the End - is also recorded in Song of Songs Rabbah 2:7, where R. Helbo discusses with R. Onya the passage which says: 'Daughters of Jerusalem, I charge you by the gazelles and by the does of the field: Do not arouse or awaken love until it so desires':

Rabbi Helbo said: There are four oaths here: that they not rebel against the kingdoms; that they not force the End; that they not reveal their mystery to the nations of the world; and that they not ascend as a wall from the Exile. Rabbi Onya said: These four oaths correspond to the four generations which forced the End and failed.... [The Children of Ephraim] gathered together and went to war, and many of them died. Why? Because they did not believe in God and did not trust His salvation, because they transgressed the End and the oath, 'lest you awaken and excite my love'.

The oldest reference to an oath prohibiting forcing the End and rebelling against the nations is from the sixth century CE, when Simeon ben Megas haKohen writes: 'You adjured the lion cubs, saying: one, that they not force the future end and one, not to rebel against the four kingdoms.' (Ravitzky I 993: 2 I4; Fleisher 2005: 598). The primeval myth of the Children of Ephraim, recorded in BT Sanhedrin 92a, carries similar imperatives.

The emphasis placed on the three oaths differs from time to time and context to context. Aviezer Ravitzky (I993: 83, 2 I2) remarks that although the traditions of the threefold oath were seen to be aggadic and thus never functioned as a direct prohibition, they generated a 'deep-seated reluctance to rebel against the Exile or to force the end'. This is exemplified by JAZ, who believe that the emergence out of exile and the restoration of the Jewish people to the Holy Land is 'strictly God's domain, and any effort in that area is a direct affront and denial of his mastery over the world' (Cohen 2007: 4). The processes of exile and redemption 'must be left to the control of God, with no physical effort on our part' (Cohen 2007: 10). To try to end the exile politically or forcibly would only 'defy divine providence'; the only way to bring about relief is to repent, as 'the fate of the Jews reflects the consequences of the Covenant between God and His people' (Rabkin 2006: I 2). Abandoning this approach is bound to have serious implications, JAZ warns:

We [the Jewish people] are in exile by Divine Decree and may emerge from exile solely via Divine Redemption. All human efforts to alter a 
metaphysical reality are doomed to end in failure and bloodshed. History has clearly borne out this teaching. (JAZ $\left.20{ }_{5} \mathrm{a}\right)$

Werblowsky concludes that embracing the exile as the way to redemption has become a meaningful strategy for Judaism (2005: 5978); it is seen as a reflection of the more profound exile of God, in which the Jewish people can participate, and thereby contribute to the redemption of God himself, his people and his creation. In this system, the role of the Messiah is diminished.

In this brand of passive messianism, it seems the domains of God, the Messiah and the Jewish people are clearer than in the active equivalent. Redemption will be brought about solely by God; the Messiah will bring the Jewish people to repentance; having accomplished that, he will gather them to the Holy Land and rebuild the Temple. Hence, the responsibilities left with the Jewish people are to repent and live piously. Whilst the Jewish people attend to these aspects, God will see to the rest. This is, according to JAZ, the way Jews have 'always believed':

Jews have always believed that first the messiah will come and afterwards all the Jews will return to the Holy Land. They will go there under the messiah's leadership.... See also the Talmud (Kesubos I I ra) which states that nowadays the Jewish people is forbidden under oath to take over the Holy Land. Clearly then, taking over Eretz Yisroel is something we cannot do on our own, before the messiah comes. We must wait for the messiah to tell us in the name of G-d that the exile is over and the oath is no longer in force. ( JAZ 20 I $_{5} \mathrm{~b}$ )

Besides BT Ketubbot i i a, JAZ also refers to Isa I I:I 2 and Mishneh Torah Melachim u Milchamot I I: I for the view that the Messiah will 'arise and restore the kingship of the house of David to its former status, build the Temple and gather in the exiles of Israel' (JAZ 2015b). NK also refers to BT Ketubbot i i a for a related view: that Jews 'shall not use human force to bring about the establishment of a Jewish state before the coming of the universally accepted Moshiach'. Furthermore, it is 'forbidden to rebel against the nations', and the Jewish people should 'not attempt to leave the exile which G-d sent us into, ahead of time' (NK $2015 \mathrm{~b})$.

Expectations as to how the Messiah will reveal himself are framed in concrete and observable circumstances, which limit the parameters of interpretation. Similar to NK, JAZ presumes the Messiah will bring the entire Jewish people to repent: 
Once he has accomplished the repentance of all the Jews, clearly Hashem is telling us that he has enough of a chezkas moshiach [presumed Messiah] to be allowed to fight wars. Once he fights the wars, he reaches an even higher level of chazakah, allowing him to gather the exiles and build the Temple.

(JAZ $\left.20{ }_{5} \mathrm{c}\right)$

Bringing the entire Jewish people to repent is an undertaking so monumental that 'no false Messiah will be able to do it and fool the world' (JAZ $2015 \mathrm{~b}$ ). If somebody were to achieve it, it would be sufficient proof that he is sustained by God and is designated to be the Messiah. By these criteria, there need not be any confusion as to who is the true Messiah; those already living a life in repentance should continue on that path. Eventually, the whole of the Jewish people will do the same and then the next step can be taken. The next step also shouldn't cloud one's mind, because then the Messiah will be there to guide the Jewish people on the way to redemption:

The messiah will be recognized by the fact that he will be a Jewish leader who brings all the Jews to repent and follow the laws of the Torah. Once he does this it may be safely assumed that he is the messiah. Once the entire Jewish and non-Jewish world has recognized him as the messiah, his next task will be to bring back the Jewish exiles and build the Temple. If he does this, then he is certainly the messiah. If he fails at this second stage or dies before completing it, then he is not the messiah. (JAZ $20{ }_{5} \mathrm{~d}$ )

Hence, there redemption is, in a paradoxical way, indeed a divine intervention and a miracle, but at the same time, redemption in its initial phase will be manifested by a feature of exile: repentance. JAZ explains that this is to ensure that false prophets cannot daze the people with grand miracles, an interpretation made by the Satmar Rav (R. Yoel Teitelbaum, I9 14-2006) in Vayoel Moshe (Cohen 2007: I 27).

The Haredim seems to be content with the traditional strategy for redemption: to wait for the Messiah, and while waiting, to live piously, repent and abide by the threefold oath. This strategy allows many questions related to redemption to be postponed:

Whatever the criteria are for the messiah, it is clear that we have to wait for him, and thus it is certainly wrong to conquer the Holy Land under a movement such as Zionism that does not even claim that any particular person is the messiah. (JAZ $20 \mathrm{I}_{5} \mathrm{~b}$ ) 
Although this form of messianism falls into the category of 'passive' (Eisen 20I I: 147-54) the enforcement of this strategy involves a persistent activism: the adherents of this perspective protest, publish books, deliver speeches and distribute pamphlets (NK 20I5 $\mathrm{c}$ ).

\section{The Hardal understanding of the Messiah}

To the voices of the Hardal perspective, as represented in this article, the Messiah is seen as vital to the coming of the ultimate redemption, but the process of redemption has already begun. Hence, the exile has ended and the Jewish people should do all in its power to contribute to the dawning redemption, even though the Messiah seems to be hanging back.

This understanding was not novel, but got off the ground in response to the establishment of the State of Israel. This remarkable break in what otherwise were ever deteriorating conditions for the diaspora in Europe was interpreted as a divine intervention to restore the Jewish people. For R. Tzvi Yehuda Kook, it was clear that the new development was the work of God. In his Independence Day Speech of 1967 , he recalls his response on hearing the news:

We sat together [the following day], the two of us [R. Zvi Kook and R.Y. M. Harlap], in that small hallowed room in 'Beit HaRav' [in the study of the late R. A. Kook] - where else if not there - we sat shocked and silent. Finally, regaining our strength, we said, the two of us as one: 'This is the L-rd's doing; It is marvellous in our eyes.' (MH 2015a)

What was equally clear was that the circumstances were far from ideal: the new state was officially secular, as was a substantial proportion of its Jewish population. This constituted a problem: if the time of redemption had indeed come, why were not all Jews inspired to repent? Why was a state, rather than a kingdom, established? Why a democracy and not a revival of the Davidic dynasty? The interpretation of the state as a work of God was firm, however, suggesting that the reinterpretation of redemption, which had now been gaining ground for half a century, was correct. R. Tzvi Yehuda Kook was convinced that the lack of piety in the Jewish state would, in time, be replaced by a hunger for the Torah and its glorification:

Indeed, surely as a result of the return of Israel to their Land there will come about the increase of Torah and its glorification. But the first step is the settlement of Israel and of their Land. HaRav Eliyahu Gutmacher 
z'tl [I 796-I 874] wrote: 'It is clear to me that if I 30 families of Israel begin to till the land in our holy Eretz - this will be the beginning of the Redemption (Geulah) even if the people are not yet worthy. (MH 2015a)

R. Tzvi Yehuda Kook's father and predecessor, R. Abraham Y. Kook, perceived the exile to be a harsh, but spiritually purifying preparation for the national and religious awakening. He saw that the burdens of exile had become too heavy for the Jewish people to bear and that the time had come for a return. The historical connection was no longer enough to sustain the nation. He was optimistic that

one spark of this real life in the homeland will revive a very vital existence. Only with the people's return to its land, which is the only route to its rebirth, will the real, sacred life of Judaism be revealed. (Don-Yehiya I992: I32)

The negation of exile was 'highly prevalent' in both secular and religious Zionist circles, Eliezer Don-Yehiya tells us that (I992: I 30-2). R. A. Kook was convinced its time had passed and that the exile had become a 'defective and alienated existence', characterized by 'decline, narrowness, displacement, seclusion and weakness'. He was hopeful that, when liberated from it, Judaism would be restored to its original nature, in which all areas of life are bound together and connected to its divine source. Under these conditions, the Jewish people would constitute a nation with institutions and an infrastructure based on and guided by the Torah, allowing a full Jewish existence, both individually and communally. R. Tzvi Yehuda Kook not only negated the exile but excluded the diaspora from the 'true Israel':

The true Israel is Israel redeemed, the kingdom of Israel and the armies of Israel, a people in its wholeness and not a diaspora in exile. Thus, when Israel was sent into exile heavens and earths throughout the universe trembled. And so it was with the coming of the Geulah (Redemption). A tremor spread through the universe, billowing from step to step until it reached us.... The process is gradual and continuous, and each and every year [of Israel's independence] is a new hymn, a celestial song, another link in the chain. ( $\left.\mathrm{MH}_{20} \mathrm{I}_{5} \mathrm{a}\right)$

The impression of Ravitzky ( 1993 : I 35, 98) is that undoubtedly, R. A. Kook perceived Zionism as 'a human response to a divine call'. Therefore, the death 
of Theodor Herzl presented R. A. Kook with a difficulty: how to view the man, who made no claim to be a religious figure, but still was the primus motor of a divine intervention. R. Kook's solution was found in classical Jewish messianic imagery: he drew parallels between the legendary figure Messiah ben Joseph and Herzl. Both were messianic figures paving the way for the ultimate redeemer, Messiah ben David, and both were determined to fall in battle, making a crucial contribution to redemption, but not bringing it to completion.

To turn to a currently active representative of the Hardal perspective, the Temple Institute based its understanding of the role of the Messiah on the idea of a progressive path to redemption. The military triumph of the Six Day War in 1967 - with the conquest of the Temple Mount at its climax - was interpreted by many religious Zionists as a divine intervention to bring about the final redemption. Among the paratroopers conquering the Temple Mount was R. Yisrael Ariel, who recalls:

No one who was privileged enough to witness this moment, and whose feet stood on the Lord's mountain after thousands of years of Jewish absence, could fail to be elated by the great moment for the Jewish people. These are the Days of Messiah - there is no other expression for it.... I arrived at the Western Wall, and below me I saw two old men - none other than my two rabbis and teachers from the yeshiva, Rabbi Zvi Yehuda Kook ZTS'L and the 'Reclusive Rabbi' ZTS'L [David HaCohen, a.k.a. the Nazir]. We embraced and stood with tears running down our cheeks, in complete silence, sensing that Messiah was still on the way - it would just take another hour or two.' (TI 201 5a; Inbari 2009: 33-47)

But as time passed by and the Messiah did not appear, a sense of disappointment dismantled the magical experience. The crisis at the Western Wall caused R. Yisrael Ariel to reconsider his eschatological expectations. His ruminations over the years that followed led him to the conclusion that the Temple was the missing link in the chain of redemption:

Through the years, the more I studied, the more I began to understand that we had only ourselves and our own inaction to hold accountable: G-d does not intend for us to wait for a day of miracles. We are expected to act. We must accomplish that with which we have been charged: to do all in our power to prepare for the rebuilding of the Holy Temple, and the renewal of the divine service. (TI $2015 \mathrm{~b}$ ) 
R. Ariel thus laid the blame for the absent redemption on the Jewish people, ${ }^{6}$ for 'waiting for a day of miracles' instead of rebuilding the Temple of Jerusalem, which has 'the power to hasten the advent of the Messiah and bring about the final redemption' (Ariel and Richman 2005: I). From that realization onwards, rebuilding the temple became his mission. As with the process of redemption, rebuilding the Temple is seen as a process, advancing slowly but steadily:

The rebuilding would happen, even if it happens very slowly, and in stages, one step at a time. For like the morning dawn, 'such is the way of Israel's redemption. In the beginning, it progresses very slowly... but as it continues, it grows brighter and brighter.' (TI 201 $5 \mathrm{c}$ )

For this purpose, R. Ariel founded the Temple Institute (TI), an organization based on 'the principle of action', with the ambition to 'provide a basis in research, planning and infrastructure for the Third Temple' (TI $2015 \mathrm{~d}$ ). TI relates the project at hand to that of King David:

The basis of the Institute's work is the commandment given to the Jewish people at Mount Sinai, And they shall make for Me a Sanctuary, and I will dwell amongst them (Ex. 25:8). The Institute's efforts towards preparing for the Temple in our time can be compared to the preparations that were done in the days of the tabernacle and later, by King David. (TI $20{ }_{5} \mathrm{~d}$ )

Over time, the emphasis on the Temple as a crucial aspect of the unfolding redemption was outweighed by the emphasis that building a temple is a commandment, and all of God's commandments are incumbent. Both of these ideas fulfil their function: the first evens out the cognitive dissonance that was created when redemption did not erupt despite the promising signs in $1967^{7}$; the second provides an argumentation which is resistant to similar disillusionments:

6 Presumably R. Ariel is referring to the Jewish people when speaking of 'us'; however, it is not specified in the sources referred to in this article. He could, for instance, be excluding anti-Zionists or including Christian Zionists.

7 Inbari (2009: I 2-1 3, 38-9) connects Leo Festinger's theory of cognitive dissonance to the ideo-theological development of R. Yisrael Ariel. The theory of cognitive dissonance presumes that it occurs when a prophecy has failed, that is, when it has been proven to be a miscalculation. Inbari's examination suggests that if cognitive dissonance also occurs when a prophecy does not have an end date it therefore does not fail, per se. He proposes that messianic radicalization may be a reaction to cognitive dissonance. But although the theory of cognitive dissonance assumes that a movement, on finding its belief system challenged, will undergo a process of radicalization, it does 
There is no question about the fact that at the time G-d wills it, the messiah will arrive. This is a great promise that $\mathrm{He}$ made, and nothing can happen that will change that. But this has nothing to do with our obligations to G-d! Those also do not change! The messiah's job is not to come and tell us, 'Now, it is time for you to fulfil this or that particular commandment.' For the commandments are always to be fulfilled by Israel, at all times, to the best of our ability. (TI 20 I $_{5} \mathrm{e}$ )

When stressing the perpetuity of fulfilling the commandment to build a sanctuary for God, rather than stressing its importance for the process of redemption, the order of events falls out of focus. Even if some traditions suggest the Messiah will precede the rebuilding of the Temple, it does not call for a change in the plan of action, since the plan for action is based on adherence to the commandments, rather than on the understanding of redemption. Nevertheless, TI interprets Maimonides as indicating that rebuilding the Temple will, in fact, precede the coming of the Messiah: ${ }^{8}$

if there really is a question as to 'Which comes first, the Messiah or the Temple,' there seems to be ample indication that the building of the Holy Temple will precede the Messiah's arrival. Various Biblical verses and statements made by the great sages prove this. This is actually the opinion of Maimonides, who quotes an astounding verse from the prophecy of Malachi (3:I) in his classic Letter to Yemen: 'For suddenly the master whom you are seeking will come to his sanctuary. (TI 2015e)

Another way to downplay the importance of the Messiah, and hence, to reduce the problem of his absence, is to widen the scope of interpretation. TI elaborates on the possibility of messianic manifestation and messianic potential. In Hilchot Ta'aniot 5 and Hilchot Melachim I I, Maimonides describes Bar Kochba as 'a great king whom all of Israel, including the great sages, was convinced was the Messiah'. From these words, according to TI, it is reasonable

not necessarily mean that the movement has acknowledged its beliefs to be errant; it may instead, Inbari argues, both radicalize and pursue a logical explanation for its error. Cognitive dissonance may thus occur not only from acknowledging a mistake but also from the fear of being wrong, and lead to radicalization.

8 The passage from Maimonides' Letter to Yemen cited here reads: 'Regarding the question of how and where Mashiach will appear; we know he will make his first appearance in Eretz Yisrael. As it says, "Suddenly he will come to His temple" (Malachi 3:I). But no one will know how he will arise until it actually happens.' (Finkel I 996: 40-I). 
to perceive Bar Kochba's attempt to reinstitute the monarchy and gather the exiles as messianic manifestation by Jewish law. Although Bar Kochba's attempts failed, they had a messianic potential:

From Maimonides' words, we understand that Bar Kokhba's attempt to restore the kingdom to Israel and return the nation to its land is clearly defined by Jewish law as messianic manifestation. Thus a fast was decreed for all generations to mourn the failure of this process. In other words, the attempts of Bar Kokhba had messianic potential. (TI 20 I $5 \mathrm{e}$ )

In the Book of Daniel (7:13), the Messiah is portrayed arriving on clouds of heaven. The Book of Zechariah (9:9), on the other hand, portrays the Messiah arriving modestly, riding on a donkey. A discussion concerning this discrepancy is carried out in BT Sanhedrin 98a. The fruit of the discussion, TI concludes, is that how the Messiah will arrive is not fixed. He may arrive in splendour and grandeur, if Israel has proven itself worthy of him, but he may also appear in humbleness and stillness, if Israel is unworthy (TI $20 \mathrm{I}_{5} \mathrm{e}$ ). However, the unforthcoming Messiah does not challenge the idea that redemption is there 'for the taking':

The opportunity for redemption - geula - is also always at hand - for those who seek it urgently, for those who are willing discard their appointment books and personal calendars, jettison their vacation plans, reorder their priorities, and make all holy haste to grab it. When the sense of urgency is upon us, when geula is for us the only option, so compelling that we are unable to hesitate, then redemption is ours for the taking. (TI $20{ }_{5} \mathrm{f}$ )

\section{Conclusions}

In this article, we have acquainted ourselves with the Haredi and Hardal perspectives on redemption in general, and on the role of the Messiah in particular, as expressed by a handful of rabbis and organizations. We have seen that historical events such as the establishment of the State of Israel and the Six Day War, have promoted a development in their respective understandings of redemption. The parting of ways between the two has so far been sustained. However, there are some indications of a break in this trend.

There is a temptation to polarize these perspectives, although, in toto, they are in agreement on crucial aspects of redemption. Both believe in an approaching redemption; both believe that the Messiah will play a crucial role in it; 
both believe that the Messiah will appear at a time of God's choosing. The disagreement concerns the shift from exile to redemption: how and by whom it will be brought about. However, from the solutions to this question, two respective plans of action are derived. These are, in many respects, poles apart. To the Haredim, the solution calls for the Jewish people to repent, live piously and wait; to the Hardalim, the solution calls for the Jewish people to abandon the passive approach and see that 'redemption is there for the taking', as TI expresses it. Hence, both present a strategy for expediting the End, and can thus be considered messianic.

The Messiah is, to the Haredim, an integral aspect of the shift from exile to redemption. He is the marker that exile has ended and that redemption has begun, which opens a world of new possibilities. But until he has emerged, the Jewish people are in exile and abide by the restrictions of exile. To the Hardalim, the Messiah is crucial to the impetus of the ultimate redemption, but what function he will fulfil during the shift from exile to redemption - during the process of redemption - is less clear. As (the Hardal interpretation of) history has shown, he was not needed to redeem Israel from its subjugation to the nations; he was not needed to gather the exiles or to wage war; the rebuilding the Temple has been prepared for without his guidance. Hence, the process of redemption proceeds even without the Messiah being physically present. The question is, therefore, whether there are any realms related to redemption which are exclusively assigned to the Messiah, or is he invited as a guest to an already set table?

Mia Anderssén-Löf, MA, is a doctoral student in Jewish studies in the Faculty of Arts, Psychology and Theology of Åbo Akademi University. Her research interests include theological constructs of contemporary Jewish movements, the processes of radicalization and the interface between theological and sociopolitical developments.

\section{Primary sources}

\section{Publications}

Ariel, Yisrael, Chaim Richman, 2005. Carta's Illustrated Encyclopedia of The Holy Temple in Jerusalem (Jerusalem, Temple Institute)

Babylonian Talmud, r 989-94. Hebrew-English Edition of the Babylonian Talmud, trans., ed. Isidore Epstein (London, Soncino Press)

Cohen, Yirmiyahu, 2007. In the Footsteps of the Flock: The Views of the Gedolei Hatorah on Exile, Redemption and Eretz Yisroel, Arranged According to the Weekly Torah Readings (New York, A Natruna Publication)

International Bible Society, I 979. New International Version Anglicised (London, Hodder \& Stoughton Publishers) 
Rabkin, Yakov M., 2006. A Threat from Within: A Century of Jewish Opposition to Zionism (Canada, Fernwood Publishing)

\section{Web sources}

\section{Mercaz Harav Yeshiva}

MH 20 I 5 a, <www.mercazharav.org/mizmori g.htm> (accessed 26.I.20I 5)

MH 20I 5b, <www.mercazharav.org/about.htm> (accessed 2 I.I.201 5)

MH 20 I 5 c, <www.mercazharav.org/kook.htm> (accessed I.IO.20I4)

\section{Neturei Karta}

NK 2015a, <www.nkusa.org/books/index.cfm> (accessed 24.2.2015)

NK 20I 5 b, <www.nkusa.org/aboutus/index.cfm> (accessed I 2.I.2015)

NK 20 I $_{5}$ c, <www.nkusa.org/activities/recent/index.cfm> (accessed 3.I I.20 I 5)

\section{The Temple Institute}

TI 2015 a, <www.templeinstitute.org/about.htm\#directors> (accessed 24.I.20I 5 )

TI 20I 5 b, <www.templeinstitute.org/about.htm\#Rabbi-Ariel> (accessed 24.I.20I 5)

TI 20I5c, <www.templeinstitute.org/red_heifer/tenth_red_heifer.htm> (accessed

24.I.2OI 5 )

TI $2015 \mathrm{~d}$, <www.templeinstitute.org/about.htm> (accessed 23. I.20I I)

TI 2015 e, <www.templeinstitute.org/messiah_temple.htm> (accessed 2 I.2.20I 5)

TI 2015 f, <www.templeinstitute.org/talk/Nisan_8_5770-March_23_20Io.htm> (accessed 26.2.2015)

\section{True Torah Jews against Zionism}

JAZ 2015 a, <www.truetorahjews.org/our_mission> (accessed 24.9.2014)

JAZ 2015 b, <www.truetorahjews.org/qanda/messiah I > (accessed 8.I.2015)

JAZ 20 I $_{5}$ c, <www.truetorahjews.org/qanda/messiah> (accessed IO.I.201 5)

JAZ ${ }_{20}$ I $_{5}$ d, <www.truetorahjews.org/qanda/recognizemessiah> (accessed 8.I.201 5 )

\section{Secondary sources}

Antoun, Richard T., 2001. Understanding Fundamentalism: Christian, Islamic and Jewish Movements (Boston, Altamira Press)

Arian, Asher, 2009. 'Israel: the challenge of a democratic and Jewish state' in Secularism, Women E the State: The Mediterranean World in the $21^{\text {st }}$ Century, eds Barry A. Kosmin and Ariela Keysar (Hartford, Institute for the Study of Secularism in Society and Culture), pp. 77-90

Cohen, Asher, and Aaron Kampinsky, 2006. 'Religious leadership in Israel's religious Zionism: the case of the Board of Rabbis', Jewish Political Studies Review, I $8(3 / 4)$, pp. I I $9-40$

haCohen, Mordechai, et al., 2007. 'Land of Israel: religious life and communities' in Encyclopaedia Judaica, vol. Io, eds Michael Berenbaum and Fred Skolnik, 2nd edn (Detroit, Macmillan Reference), pp. 619-52 
Cohen, Yoel, 20 I 4. God, Jews and the Media: Religion and Israel's Media (New York, Routledge)

Don-Yehiya, Eliezer, I 992. 'The negation of galut in religious Zionism', Modern Judaism, I 2, pp. I 29-55

Eisen, Robert, 20 I I. Peace and Violence in Judaism: From the Bible to Modern Zionism (New York, Oxford University Press)

Feige, Michael, 2009. Settling in the Hearts: Jewish Fundamentalism in the Occupied Territories, Raphael Patai Series in Jewish Folklore and Anthropology (Detroit, Wayne State University Press)

Festinger, Leon, Henry W. Riecken, and Stanley Schachter, I 964. When Prophecy

Fails: A Social and Psychological Study of a Modern Group that Predicted the Destruction of the Modern World (New York, Harper Torchbooks)

Finkel, Avraham Yaacov, I 996. The Essential Maimonides: Translations of the Rambam New York, Jason Aronson Inc.)

Fishman, Aryei, and Mordechai Inbari, 2or r. 'Religious Zionism' in The Oxford Dictionary of the Jewish Religion, ed. Adele Berlin, and edn (New York, Oxford University Press, Inc.

Firestone, Reuven, 20I 2. Holy War in Judaism: The Fall and Rise of a Controversial Idea (New York, Oxford University Press)

Friedman, Menachem, 2007. 'Neturei Karta' in Encyclopaedia Judaica, vol. I 5 , ed. Michael Berenbaum and Fred Skolnik, 2nd edn (Detroit, Macmillan Reference

Friedman, Menachem, and David Derovan, 2007. 'Blau, Amram' in Encyclopaedia Judaica, vol. 3, eds Michael Berenbaum and Fred Skolnik, 2nd edn (Detroit, Macmillan Reference), pp. 742

Goldwater, Raymond, 2009. Pioneers of Religious Zionism: Rabbis Alkalai, Kalischer, Mohliver, Reines, Kook and Maimon (Jerusalem, Urim Publications)

Heilman, Samuel C., and Fred Skolnik, 2007. 'Haredim' in Encyclopaedia Judaica, vol. 8, eds Michael Berenbaum and Fred Skolnik, 2nd edn (Detroit, Macmillan Reference), pp. 348-52

Inbari, Motti, 2009. Jewish Fundamentalism and the Temple Mount: Who Will Build the Third Temple? (Albany, State University of New York Press)

Katz, Jacob, 2007. 'Zionism' in Encyclopaedia Judaica, vol. 2 I, eds Michael Berenbaum and Fred Skolnik, 2nd edn (Detroit, Macmillan Reference), pp. 539-627

Kraemer, Joel L., 2006. 'Moses Maimonides: an intellectual portrait' in Cambridge Companion to Maimonides, ed. Kenneth Seeskin (New York, Cambridge University Press)

Lustick, Ian S., I 988. For the Land and the Lord: Jerwish Fundamentalism in Israel (New York, Council of Foreign Relations Press)

Morgenstern, Arie, 2006. Hastening Redempion: Messianism and Resettlement of the Land of Israel (New York, Oxford University Press)

Myers, Jodi Elizabeth, r 99r. 'The messianic idea and Zionist ideologies' in Jerws and 
Messianism in the Modern Era: Metaphor and Meaning, ed. Jonathan Frankel, Studies in Contemporary Jewry: An Annual VII (Hebrew University of Jerusalem and Oxford University Press, New York)

O'Leary, Stephen D., 2000. 'When prophecy fails and when it succeeds: apocalyptic prediction and the re-entry into ordinary time' in Apocalyptic Time, ed. Albert I. Baumgarten (Leiden, Koninklijke Brill NV)

Rabinowitz, Louis Isaac, 2007. 'Ingathering of the exiles' in Encyclopaedia Judaica, vol. 9, eds Michael Berenbaum and Fred Skolnik, 2nd edn (Detroit, Macmillan Reference), pp. 786-7

Ravitzky, Aviezer, I 993. Messianism, Zionism and Jerwish Religious Radicalism (The University of Chicago Press)

Rubinstein, Avraham, 2007. 'Teitelbaum' in Encyclopaedia Judaica, vol. I 9, eds Michael Berenbaum and Fred Skolnik. 2nd edn (Detroit, Macmillan Reference), pp. $582-3$

Sacks, Jonathan, 1992. Crisis and Covenant: Jewish Thought after the Holocaust (Manchester University Press)

Sagiv-Feldman, Yael, 1979. 'Living in deferment: Maimonides vs. Nahmanides on the Messiah, redemption and the world to come', Hebrew Studies, 20/2 I (I979-80), pp. I07-I6

Scholem, Gershom, I 97r. The Messianic Idea in Judaism and Other Essays on Jewish Spirituality (New York, Schocken Books Inc.)

Schwartz, Dov, 2002. Faith at the Crossroads: A Theological Profile of Religious Zionism (Leiden, The Brill Reference Library of Ancient Judaism)

-2009. Religious-Zionism: History and Ideology (Brighton, Academic Studies Press)

Sharot, Stephen, I 982. Messianism, Mysticism and Magic: A Sociological Analysis of Jewish Religious Movements (Chapel Hill, The University of North Carolina Press)

Shelef, Nadav G. 2o ro. Evolving Nationalism: Homeland, Identity and Religion in Israel, I 92 5-2005 (Ithaca, Cornell University Press)

Vital, David, I 989. Zionism: The Formative Years (New York, Oxford University Press)

Werblowsky, R. J. Zwi, 2005. 'Messianism: Jewish Messianism' in Encyclopedia of Religion, vol. 9, ed. Lindsay Jones, 2nd edn (Detroit, Macmillan Reference), pp. $5974^{-9}$ 